\title{
Perspectives of Teacher Candidates on the Statements Related to Effect of Politics on Lecturers and Educational Administrators' Competence of Ensuring Unity
}

\author{
İhsan Nuri Demirel \\ Department of Educational Sciences Educational Management, Faculty of Education, Ağrı Ibrahim Cecen University, Turkey
}

Copyright $(2018$ by authors, all rights reserved. Authors agree that this article remains permanently open access under the terms of the Creative Commons Attribution License 4.0 International License

\begin{abstract}
This study aims to find out the attitude of teacher candidates of Ağrı İ.Ç. University Faculty of Education who study at the Department of Elementary Turkish Education to the statements related to effect of politics on lecturers and educational administrators' competence of ensuring unity. A-) The statements accepted as effect of politics on lecturers that consisting following statements: Lecturers work without being influenced by dominant politic powers, lecturers don't think the students who have high political activity as superior to the other students, lecturers work without being influenced by the political views of their principals, lecturers work without bestowing privilege on the students who are on the side of local politic powers, lecturers assess the students who don't share the same politic views with them objectively. B-) The statements related to educational administrators' competence of ensuring unity that consisting following statements: Educational administrators don't discriminate between the people who work at their service, educational administrators don't appoint the people with whom they have consensus on the same political views with certain authorities, educational administrators don't favour the unqualified employees who have the same political view with them, educational administrators don't prevent qualified employees who don't have the same political view from getting promotion, educational administrators do everything in their power to make all the employees who have different political view unified. A survey which includes questions related to A-) effect of politics on lecturers and B-) educational administrators' competence of ensuring unity are conducted to determine the attitudes of teacher candidates towards A-) effect of politics on lecturers and B-) educational administrators' competence of ensuring unity. Research sampling consists of 121 teacher candidates of Ağrı İ.Ç. University Faculty of Education who study at the Department of Elementary
\end{abstract}

Turkish Education. According to findings of the research teacher candidates have answered the questions containing information on A-) The Statements Related to Effect of Politics on Lecturers and B-) The Statements Related to Educational Administrators' Competence of Ensuring Unity with variable rates. The findings make it possible to come to that conclusion that teacher candidates have responded to scale which is reliable according to its Cronbach's Alpha value $(\alpha=0.91)$ in varying ratios as given in Field [5].

Keywords The Statements Related to Effect of Politics on Lecturers, The Statements Related to Educational Administrators' Competence of Ensuring Unity

\section{Introduction}

As the stated in the book of Başaran [2], when the topic is analyzed from the viewpoint of the following statement "Lecturers work without being influenced by dominant politic powers." it is possible to understand the importance of which lecturers are not influenced by the dominant political view from the educational organization and the general politic organization that includes educational organization while they are doing their duties. No matter what happens, lecturers shouldn't project their political views on their duties. It doesn't mean that they shouldn't have any political view. As a matter of course, it is possible that lecturers have political views. There is nothing to be considered wrong related to having political views in terms of lecturers. The fact that lecturers who should objectively perform their duties shouldn't project their political views on their duties is the important point.

According to the Demirel [4], when the topic is analyzed 
from the viewpoint of the following statement "Lecturers don't regard the students who have high political activity as superior to the other students." it is seen that lecturers should train students regardless of their personal identifying information, social class, financial income status, Besides the lecturers' fallacy of thinking the students who have high political activities as superior to the other students who don't have these powers, the administrators who are part of education management organization shouldn't favour the candidate teachers who have political powers and they shouldn't behave them differently when compared with the other teacher candidates who don't have political Powers.

According to the study of Kaya [6], when the research topic is evaluated from the viewpoint of the following statement "Lecturers work without being influenced by the political views of their principals", it is seen that they should perform their duties without being enslaved by the dominant political view of their habitual place of abode. They should work without being influenced by the dominant political view that has controlled over the education management organization in which they fulfill their duties. Lecturers should work without being affected by the administers of the education management organization in which they work. When the lecturers manage to work without being affected by the political views of the administers of the education management organization, they will get rid of behaving politically while communicating with teacher candidates.

As the stated in Bursalıoğlu [3], when the research topic is evaluated from the viewpoint of the following statement "Lecturers work without bestowing privilege on the students who are on the side of local politic powers." it can be seen that lecturers should avoid the local impositions in the settlement in which includes the educational institutions of lecturers. In addition to the lecturers, administers of educational institutions in which lecturers work should stand out against the local powers which are active in the settlement in which includes the educational institutions. The fact that educational institutions in which lecturers work put some distance between politic powers and they makes the lecturers relaxed. Those teacher candidates put pressure on the educational institutions and lecturers by pulling some strings by the help of local powers should be considered as a problem that must be controlled.

When the topic is investigated from the viewpoint of the following statement "Lecturers assess the students who don't share the same politic views with them objectively", importance of lecturers' politic impartiality comes to light. Lecturers shouldn't forget that their students who are their target groups are composed of people who have different political views. Lecturers should check their political views in the cloakroom of their educational institutions before they get inside the mentioned institutions. Before they get inside the educational institutions in which they work, they should receive their "teacher hat" from which they have hooked their "politics hat" in the cloakroom of their educational institutions and they have to get inside there with "teacher hat". When considered from this point of view, lecturers are responsible to behave and evaluate their students who don't have same politic view with the lecturers objectively.

When the topic is considered from the viewpoint of the following statement "Educational administrators don't discriminate between the people who work at their service", the importance of educational administrators' impartiality can be seen. Educational administrators who manage the educational management organizations are accountable to the employees who work in their institutions for treating them fairly. That educational administrators treating the employees who work in their institutions fairly and objectively shouldn't be seen as virtue, but it should be seen as ordinary part of their job and ordinary procedures. The ones who manage the educational management organization should distribute the opportunities that are obtained from the economic resources of the organizations between the employees in a planned, balanced and fair manner.

In Taymaz [7], when the topic is analyzed from the viewpoint of the following statement, "Educational administrators don't appoint the people with whom they have same political view with certain positions" it can be seen that it is important to value the competence for educational administrators. When educational administrators appoint someone with positions, they shouldn't think politic views of these people are whether the same with their politic view or not. When they employ someone, educational administrators should think how these people can make the educational institution more productive.

When the topic is considered from the viewpoint of the following statement, "Educational administrators don't favour the unqualified employees who have the same political view with them" it can be understood that educational administrators shouldn't favour unqualified people in the educational organizations. It is not acceptable that administrators of the educational management organizations favour unqualified people who are close to the administrators of educational management organization and appoint them with important positions.

When the topic is investigated from the viewpoint of the following statement "Educational administrators don't prevent qualified employees who don't have the same political view from getting promotion." preventing qualified people from getting promotion can be seen as injustice and wrongness. As mentioned above, it is not fair that the administrators of educational management organization invest unqualified people with important positions in the institution just because these people are close to them. Similarly, it is also not fair that administrators prevent qualified people from getting 
promotion just because these people are not close to them. Also, it is not something explainable.

When the topic is analyzed from the viewpoint of the following statement "Educational administrators do everything in their power to make all the employees who have different political view unified", it is possible to understand that educational administrators make all the employees in the institutions unified is really important.

In order to make the people who have different point of views unified, educational administrators try to solve the problem by reconciling people, establishing a buffer zone, making the employees communicate instead of written procedures such as imposing penalty on them. Also, it can be more useful for the institution as Adem mentioned in [1]. Mangin and Stoelinga [8], Hawley \& Valli [9] and Garet et. Al. [10] have reported that factors such as teaching, school collaboration, interaction, guidance, student learning should be emphasized in the process of teacher training.

\section{Method}

The scope of questionnaires used as data collection tool for the attitude of teacher candidates of Ağrı İ.Ç. University Faculty of Education who study at the Department of Elementary Turkish Education to the statements related to A) effect of politics on lecturers and B) educational administrators' competence of ensuring unity has been developed pursuant to the objective of the research. The survey forms are habilitated for the information process technique by conferring with the opinions of the personnel who are knowledgeable about this topic. Trial forms prepared within this framework are applied to two different groups in the Ağrı İ.Ç. University Faculty of Education. According to findings of trial forms, it is seen that certain questions don't work. In order to enable validity which shows the expediency degree of an assessment tool and reliability which shows the consistency criterion of an assessment tool, non-operational questions have been excluded from the survey form for establishing its final form in terms of the scope and layout. The data gathered from the questionnaires applied to of teacher candidates of Ağrı İ.Ç. University Faculty of Education who study at the Department of Elementary Turkish Education have been analyzed with respect to objective of research. At the end of this analysis processes, we have reached to the results. To conclude the results, we have transferred the data to the tables.

Teacher candidates of who participate to the survey are requested to grade accuracy level related to their point of view on the statements related to A) effect of politics on lecturers and B) educational administrators' competence of ensuring unity as "Strongly disagree", "Disagree", "Neutral/Neither agree nor disagree", "Agree", "Strongly agree". These degrees are graded, respectively, 1 , $2,3,4$ and 5 . In this way, degrees of accuracy are converted into percentages.

\section{Population and Sample}

Universe of the research is composed of teacher candidates of Ağrı İ.Ç. University Faculty of Education who study at the Department of Elementary Turkish Education. Lists of teacher candidates of Ağrı İ.Ç. University Faculty of Education who study at the Department of Elementary Turkish Education are based on the ground of detecting the universe. Since it is fundamental to reach most of the teacher candidates, it is possible to state that sample data resembles the population. This research is conducted on a group consisting of 121 teacher candidates of Ağrı İ.Ç. University Faculty of Education who study at the Department of Elementary Turkish Education. Participation of teacher candidates of Ağrı İ.Ç. University Faculty of Education who study at the Department of Elementary Turkish Education were purposed within the sampling, this purpose is achieved substantially. Additionally while taking percentage of the research the fractions have not been included in the research. If there are tables in which the rate of a hundred per cent is not reach or if there is a lack of total number of "Positive Choices" such as" Agree" and "Totally Agree", the lack of fractional numbers can be seen as the reason of them.

\section{Data Gathering}

All of the 121 teacher candidates have answered the survey. None of the surveys are invalid. The survey is answered by nearly all of the teacher candidates of Ağrı İ.Ç. University Faculty of Education who study at the Department of Elementary Turkish Education. The teacher candidates have been requested to fill the survey forms in a convenient manner and hand in to the researcher.

\section{Problem}

The present research aims at finding out on what level the point of views of the teacher candidates of Ağrı İ.Ç. University Faculty of Education who study at the Department of Elementary Turkish Education on the statements related to A) effect of politics on lecturers and B) educational administrators' competence of ensuring unity.

\section{Sub-problem}

What is the level of perspectives of the teacher candidates of Ağrı İ.Ç. University Faculty of Education who study at the Department of Elementary Turkish Education on the statements related to A) effect of politics on lecturers and B) educational administrators' competence of ensuring unity?

\section{Hypotheses}

The level of perspectives of the teacher candidates of 
Ağr1 İ.Ç. University Faculty of Education who study at the Department of Elementary Turkish Education on the statements related to A) effect of politics on lecturers and B) educational administrators' competence of ensuring unity is in" desired" level.

\section{Premises}

1. Pre-testing conducted to develop the surveys is sufficient

2. Expert views taken to develop the surveys are sufficient.

3. The views of of the teacher candidates of Ağrı İ.Ç. University Faculty of Education who study at the Department of Elementary Turkish Education consulted in the research reflect the truth.

4. The selected research methods are compatible with the aim of the present research.

5. The sample's degree of representing the population is in the desired level.

6. The survey and the questions in the survey which have been used to gather data are valid and reliable.

7. It is accepted that the data obtained by survey is valid and reliable.

\section{Restrictions}

1. This research is restricted to perspectives of the teacher candidates of Ağrı İ.Ç. University Faculty of Education who study at the Department of Elementary Turkish Education.

2. This research is restricted to resources which are accessible and surveys which are used as data gathering tool.

\section{Findings}

Perspectives of the teacher candidates of Ağrı İ.Ç. University Faculty of Education who study at the Department of Elementary Turkish Education on the statements related to A) effect of politics on lecturers and B) educational administrators' competence of ensuring unity are given by the help of the tables.

When the perspectives of teacher candidates on the statements related to A) effect of politics on lecturers and B) educational administrators' competence of ensuring unity are determined, they are asked to to grade their point of view on these topics as "Strongly disagree", "Disagree", "Neutral/Neither agree nor disagree", "Agree", "Strongly agree" As mentioned before, these degrees are graded, respectively, 1,2, 3,4 and 5 . The views of the teacher candidates on A) effect of politics on lecturers and B) educational administrators' competence of ensuring unity are shown as charts. In this research, "Agree" and "Totally Agree" is accepted as the positive choices which have high levels of realization.

\section{A-) Statements related to effect of politics on lecturers}

Table 1. Lecturers work without being influenced by dominant politic powers.

\begin{tabular}{|c|c|c|c|c|c|}
\hline & & Frequency & Percent & $\begin{array}{c}\text { Valid } \\
\text { Percent }\end{array}$ & $\begin{array}{c}\text { Cumulative } \\
\text { Percent }\end{array}$ \\
\hline \multirow{6}{*}{ Valid } & $\begin{array}{c}\text { Totally } \\
\text { Disagree }\end{array}$ & 31 & 25,6 & 25,6 & 25,6 \\
\hline & Disagree & 41 & 33,9 & 33,9 & 59,5 \\
\hline & Neutral & 21 & 17,4 & 17,4 & 76,9 \\
\hline & Agree & 27 & 22,3 & 22,3 & 99,2 \\
\hline & $\begin{array}{l}\text { Totally } \\
\text { Agree }\end{array}$ & 1 & ,8 &, 8 & 100,0 \\
\hline & Total & 121 & 100,0 & 100,0 & \\
\hline
\end{tabular}

As seen in the Table 1, 31 teacher candidates have selected "Totally Disagree", 41 teacher candidates have selected "Disagree", 24 teacher candidates have selected "Neutral", 27 teacher candidates have selected "Agree", 1 teacher candidate has selected "Totally Agree". The expectations of $30 \%$ of the teacher candidates ( 28 teacher candidates on this issue are in positive choices (regarding the sum of "Agree" and "Totally Agree" options).

Table 2. Lecturers don't think the students who have high political activity as superior to the other students.

\begin{tabular}{|c|c|c|c|c|c|}
\hline & & Frequency & Percent & $\begin{array}{c}\text { Valid } \\
\text { Percent }\end{array}$ & $\begin{array}{c}\text { Cumulative } \\
\text { Percent }\end{array}$ \\
\hline \multirow{6}{*}{ Valid } & $\begin{array}{c}\text { Totally } \\
\text { Disagree }\end{array}$ & 20 & 16,5 & 16,5 & 16,5 \\
\hline & Disagree & 27 & 22,3 & 22,3 & 38,8 \\
\hline & Neutral & 30 & 24,8 & 24,8 & 63,6 \\
\hline & Agree & 38 & 31,4 & 31,4 & 95,0 \\
\hline & $\begin{array}{l}\text { Totally } \\
\text { Agree }\end{array}$ & 6 & 5,0 & 5,0 & 100,0 \\
\hline & Total & 121 & 100,0 & 100,0 & \\
\hline
\end{tabular}

As evaluated in the Table 2, there are 20 of the teacher candidates who have selected "Totally Disagree", 27 of them have selected "Disagree", 30 of them have selected "Neutral", 38 of them have selected "Agree" and 6 of them have selected "Totally Agree". The expectations of $36 \%$ of the teacher candidates (44 teacher candidates) on this issue are in positive choices (regarding the sum of "Agree" and "Totally Agree" options).

Table 3. Lecturers work without being influenced by the political views of their principals.

\begin{tabular}{|c|c|c|c|c|c|}
\hline & & Frequency & Percent & $\begin{array}{c}\text { Valid } \\
\text { Percent }\end{array}$ & $\begin{array}{c}\text { Cumulative } \\
\text { Percent }\end{array}$ \\
\hline \multirow{6}{*}{ Valid } & $\begin{array}{c}\text { Totally } \\
\text { Disagree }\end{array}$ & 30 & 24,8 & 24,8 & 24,8 \\
\hline & Disagree & 33 & 27,3 & 27,3 & 52,1 \\
\hline & Neutral & 32 & 26,4 & 26,4 & 78,5 \\
\hline & Agree & 21 & 17,4 & 17,4 & 95,9 \\
\hline & $\begin{array}{l}\text { Totally } \\
\text { Agree }\end{array}$ & 5 & 4,1 & 4,1 & 100,0 \\
\hline & Total & 121 & 100,0 & 100,0 & \\
\hline
\end{tabular}


As seen in the Table 3, there are 30 of the teacher candidates who have selected "Totally Disagree", 33 of them have selected "Disagree",32 of them have selected "Neutral", 21 of them have selected "Agree" and 5 of them have selected "Totally Agree". The expectations of $21 \%$ of the teacher candidates (26 teacher candidates) on this issue are in positive choices (regarding the sum of "Agree" and "Totally Agree" options).

Table 4. Lecturers work without bestowing privilege on the students who are on the side of local politic powers.

\begin{tabular}{|c|c|c|c|c|c|}
\hline & & Frequency & Percent & $\begin{array}{c}\text { Valid } \\
\text { Percent }\end{array}$ & $\begin{array}{c}\text { Cumulative } \\
\text { Percent }\end{array}$ \\
\hline \multirow{6}{*}{ Valid } & $\begin{array}{c}\text { Totally } \\
\text { Disagree }\end{array}$ & 27 & 22,3 & 22,3 & 22,3 \\
\hline & Disagree & 35 & 28,9 & 28,9 & 51,2 \\
\hline & Neutral & 33 & 27,3 & 27,3 & 78,5 \\
\hline & Agree & 20 & 16,5 & 16,5 & 95,0 \\
\hline & $\begin{array}{c}\text { Totally } \\
\text { Agree }\end{array}$ & 6 & 5,0 & 5,0 & 100,0 \\
\hline & Total & 121 & 100,0 & 100,0 & \\
\hline
\end{tabular}

As seen in the Table 4, there are 27 of the teacher candidates who have selected "Totally Disagree", 35 of them have selected "Disagree", 33 of them have selected "Neutral", 20 of them have selected "Agree" and 6 of them have selected "Totally Agree". The expectations of $21 \%$ of the teacher candidates (26 teacher candidates) on this issue are in positive choices (regarding the sum of "Agree" and "Totally Agree" options).

Table 5. Lecturers assess the students who don't share the same politic views with them objectively.

\begin{tabular}{|ccc|c|c|c|}
\hline & Frequency & Percent & $\begin{array}{c}\text { Valid } \\
\text { Percent }\end{array}$ & $\begin{array}{c}\text { Cumulative } \\
\text { Percent }\end{array}$ \\
\hline \multirow{2}{*}{$\begin{array}{c}\text { Totally } \\
\text { Disagree }\end{array}$} & 42 & 34,7 & 34,7 & 34,7 \\
\hline \begin{tabular}{ccccc} 
Disagree \\
\cline { 2 - 6 }
\end{tabular} & 32 & 26,4 & 26,4 & 61,2 \\
\cline { 2 - 6 } Neutral & 22 & 18,2 & 18,2 & 79,3 \\
\cline { 2 - 6 } & Agree & 19 & 15,7 & 15,7 & 95,0 \\
$\begin{array}{c}\text { Totally } \\
\text { Agree }\end{array}$ & 6 & 5,0 & 5,0 & 100,0 \\
\hline Total & 121 & 100,0 & 100,0 & \\
\hline
\end{tabular}

As evaluated in the Table 5 , there are 42 of the teacher candidates who have selected "Totally Disagree", 32 of them have selected "Disagree", 22 of them have selected "Neutral",19 of them have selected "Agree" and 6 of them have selected "Totally Agree". The expectations of $20 \%$ of the teacher candidates ( 25 teacher candidates) on this issue are in positive choices (regarding the sum of "Agree" and "Totally Agree" options).

\section{B-) Statements related to educational administrators' competence of ensuring unity}

Table 6. Educational administrators don't discriminate between the people who work at their service.

\begin{tabular}{|c|c|c|c|c|c|}
\hline & & Frequency & Percent & $\begin{array}{c}\text { Valid } \\
\text { Percent }\end{array}$ & $\begin{array}{c}\text { Cumulative } \\
\text { Percent }\end{array}$ \\
\hline \multirow{6}{*}{ Valid } & $\begin{array}{c}\text { Totally } \\
\text { Disagree }\end{array}$ & 27 & 22,3 & 22,3 & 22,3 \\
\hline & Disagree & 40 & 33,1 & 33,1 & 55,4 \\
\hline & Neutral & 30 & 24,8 & 24,8 & 80,2 \\
\hline & Agree & 21 & 17,4 & 17,4 & 97,5 \\
\hline & $\begin{array}{l}\text { Totally } \\
\text { Agree }\end{array}$ & 3 & 2,5 & 2,5 & 100,0 \\
\hline & Total & 121 & 100,0 & 100,0 & \\
\hline
\end{tabular}

As seen in the Table 6, there are 27 of the teacher candidates who have selected "Totally Disagree", 40 of them have selected "Disagree",30 of them have selected "Neutral" 21 of them have selected "Agree" and 3 of them have selected "Totally Agree". The expectations of $19 \%$ of the teacher candidates (24 teacher candidates) on this issue are in positive choices (regarding the sum of "Agree" and "Totally Agree" options).

Table 7. Educational administrators don't invest the people with whom they have same political view with certain positions.

\begin{tabular}{|c|c|c|c|c|c|}
\hline & & Frequency & Percent & $\begin{array}{c}\text { Valid } \\
\text { Percent }\end{array}$ & $\begin{array}{c}\text { Cumulative } \\
\text { Percent }\end{array}$ \\
\hline \multirow{6}{*}{ Valid } & $\begin{array}{c}\text { Totally } \\
\text { Disagree }\end{array}$ & 36 & 29,8 & 29,8 & 29,8 \\
\hline & Disagree & 45 & 37,2 & 37,2 & 66,9 \\
\hline & Neutral & 23 & 19,0 & 19,0 & 86,0 \\
\hline & Agree & 14 & 11,6 & 11,6 & 97,5 \\
\hline & $\begin{array}{l}\text { Totally } \\
\text { Agree }\end{array}$ & 3 & 2,5 & 2,5 & 100,0 \\
\hline & Total & 121 & 100,0 & 100,0 & \\
\hline
\end{tabular}

As seen in the Table 7, there are 36 of the teacher candidates who have selected "Totally Disagree" 45 of them have selected "Disagree", 23 of them have selected "Neutral" 14 of them have selected "Agree" and 3 of them have selected "Totally Agree". The expectations of $13 \%$ of the teacher candidates (17 teacher candidates) on this issue are in positive choices (regarding the sum of "Agree" and "Totally Agree" options).

Table 8. Educational administrators don't favour the unqualified employees who have the same political view with them.

\begin{tabular}{|c|c|c|c|c|c|}
\hline & & Frequency & Percent & $\begin{array}{c}\text { Valid } \\
\text { Percent }\end{array}$ & $\begin{array}{c}\text { Cumulative } \\
\text { Percent }\end{array}$ \\
\hline \multirow{6}{*}{ Valid } & $\begin{array}{c}\text { Totally } \\
\text { Disagree }\end{array}$ & 39 & 32,2 & 32,2 & 32,2 \\
\hline & Disagree & 42 & 34,7 & 34,7 & 66,9 \\
\hline & Neutral & 21 & 17,4 & 17,4 & 84,3 \\
\hline & Agree & 14 & 11,6 & 11,6 & 95,9 \\
\hline & $\begin{array}{l}\text { Totally } \\
\text { Agree }\end{array}$ & 5 & 4,1 & 4,1 & 100,0 \\
\hline & Total & 121 & 100,0 & 100,0 & \\
\hline
\end{tabular}

As seen in the Table 8, there are 39 of the teacher candidates who have selected "Totally Disagree" 42 of 
them have selected "Disagree", 21 of them have selected "Neutral" 14 of them have selected "Agree" and 5 of them have selected "Totally Agree". The expectations of $15 \%$ of the teacher candidates (19 teacher candidates) on this issue are in positive choices (regarding the sum of "Agree" and "Totally Agree" options).

Table 9. Educational administrators don't prevent qualified employees who don't have the same political view from getting promotion.

\begin{tabular}{|c|c|c|c|c|c|}
\hline & & Frequency & Percent & $\begin{array}{c}\text { Valid } \\
\text { Percent }\end{array}$ & $\begin{array}{c}\text { Cumulative } \\
\text { Percent }\end{array}$ \\
\hline \multirow{6}{*}{ Valid } & $\begin{array}{c}\text { Totally } \\
\text { Disagree }\end{array}$ & 32 & 26,4 & 26,4 & 26,4 \\
\hline & Disagree & 29 & 24,0 & 24,0 & 50,4 \\
\hline & Neutral & 42 & 34,7 & 34,7 & 85,1 \\
\hline & Agree & 14 & 11,6 & 11,6 & 96,7 \\
\hline & $\begin{array}{l}\text { Totally } \\
\text { Agree }\end{array}$ & 4 & 3,3 & 3,3 & 100,0 \\
\hline & Total & 121 & 100,0 & 100,0 & \\
\hline
\end{tabular}

As seen in the Table 9, there are 32 of the teacher candidates who have selected "Totally Disagree" 29 of them have selected "Disagree", 42 of them have selected "Neutral" 14 of them have selected "Agree" and 4 of them have selected "Totally Agree". The expectations of $14 \%$ of the teacher candidates (18 teacher candidates) on this issue are in positive choices (regarding the sum of "Agree" and "Totally Agree" options).

Table 10. Educational administrators do everything in their power to make all the employees who have different political view unified.

\begin{tabular}{|c|c|c|c|c|c|}
\hline & & Frequency & Percent & $\begin{array}{l}\text { Valid } \\
\text { Percent }\end{array}$ & $\begin{array}{c}\text { Cumulative } \\
\text { Percent }\end{array}$ \\
\hline \multirow{6}{*}{ Valid } & $\begin{array}{c}\text { Totally } \\
\text { Disagree }\end{array}$ & 34 & 28,1 & 28,1 & 28,1 \\
\hline & Disagree & 40 & 33,1 & 33,1 & 61,2 \\
\hline & Neutral & 29 & 24,0 & 24,0 & 85,1 \\
\hline & Agree & 14 & 11,6 & 11,6 & 96,7 \\
\hline & $\begin{array}{c}\text { Totally } \\
\text { Agree }\end{array}$ & 4 & 3,3 & 3,3 & 100,0 \\
\hline & Total & 121 & 100,0 & 100,0 & \\
\hline
\end{tabular}

As seen in the Table 10, there are 34 of the teacher candidates who have selected "Totally Disagree" 40 of them have selected "Disagree", 29 of them have selected "Neutral" 14 of them have selected "Agree" and 4 of them have selected "Totally Agree". The expectations of $14 \%$ of the teacher candidates (18 teacher candidates) on this issue are in positive choices (regarding the sum of "Agree" and "Totally Agree" options).

\section{Results}

Attitude of $30 \%$ of the candidate teachers (28 candidate teachers) to the statement that "Lecturers work without being influenced by dominant politic powers" is in positive choices (regarding the sum of "Agree" and "Totally Agree" options). According to our findings, $70 \%$ of the candidate teachers do not believe that lecturers work without being influenced by dominant politic powers.

Attitude of $36 \%$ of the candidate teachers (44 candidate teachers) to the statement that "Lecturers don't think the students who have high political activity as superior to the other students" is in positive choices. More than $60 \%$ of the candidate teachers think that lecturers think the students who have high political activity as superior to the other students.

Attitude of $21 \%$ of the candidate teachers (26 candidate teachers) the statement that "Lecturers work without being influenced by the political views of their principals" is in positive choices. We can express that nearly $80 \%$ of the candidate teachers do not accept that lecturers work without being influenced by the political views of their principals.

Attitude of $21 \%$ of the candidate teachers (26 candidate teachers) to the statement that "Lecturers work without bestowing privilege on the students who are on the side of local politic powers" is in positive choices. It can be aroused that nearly $80 \%$ of the candidate teachers do not believe that lecturers work without bestowing privilege on the students who are accompanying to local politic powers.

Attitude of $20 \%$ of the candidate teachers (25 candidate teachers) to the statement that "Lecturers assess the students who don't share the same politic views with them objectively." is in positive choices. On the light of our findings, we can conclude that $80 \%$ of the candidate teachers do not believe that lecturers evaluate the students who don't share the same politic views with them objectively.

Attitude of $19 \%$ of the candidate teachers (24 candidate teachers) to the statement that "Educational administrators don't discriminate between the people who work at their service." is in positive choices. It is observed that more than $80 \%$ of the candidate teachers do not believe that educational administrators don't discriminate between the people who work at their service.

Attitude of $13 \%$ of the candidate teachers (17 candidate teachers) to the statement that "Educational administrators don't invest the people with whom they have same political view with certain positions." is in positive choices. It is observed that nearly $90 \%$ of the candidate teachers believe that Educational administrators don't appoint the people with whom they have same political view with certain positions.

Attitude of $15 \%$ of the candidate teachers (19 candidate teachers) to the statement that "Educational administrators don't favour the unqualified employees who have the same political view with them" is in positive choices. It is seen that more than $80 \%$ of the candidate teachers say that educational administrators favour the unqualified employees who have the same political view with them.

Attitude of $14 \%$ of the candidate teachers (18 candidate teachers) to the statement that "Educational administrators 
don't prevent qualified employees who don't have the same political view from getting promotion" is in positive choices. It is seen that more than $80 \%$ of the candidate teachers think that educational administrators prevent qualified employees who don't have the same political view from getting promotion.

Attitude of $14 \%$ of the candidate teachers (18 candidate teachers) to the statement that "Educational administrators do everything in their power to make all the employees who have different political view unified." is in positive choices. It is seen that nearly $90 \%$ of the candidate teachers don't believe that educational administrators do everything to make all the employees together who have different political view unified.

\section{Suggestions}

As a consequence of the fact that attitude of $30 \%$ of the candidate teachers ( 28 candidate teachers) to the statement that "Lecturers work without being influenced by dominant politic powers" is in positive choices, an ambience that enables the lecturers work without being influenced by the dominant politic powers should be created.

As a result of the fact that attitude of $36 \%$ of the candidate teachers ( 44 candidate teachers) to the statement that "Lecturers don't think the students who have high political activity as superior to the other students" is in positive choices, lecturers should become conscious in order not to think the students who have high political activity as superior to the other students.

In view of the fact that attitude of $21 \%$ of the candidate teachers (26 candidate teachers) the statement that "Lecturers work without being influenced by the political views of their principals" is in positive choices, it should be explained to lecturers that they should work without being influenced by the political views of their administers.

As a consequence of the fact that attitude of $21 \%$ of the candidate teachers ( 26 candidate teachers) to the statement that "Lecturers work without bestowing privilege on the students who are on the side of local politic powers" is in positive choices, it should be explained to lecturers that lecturers work without bestowing privilege on the students who are accompanying to local politic powers.

Bearing in mind that attitude of $20 \%$ of the candidate teachers (25 candidate teachers) to the statement that "Lecturers assess the students who don't share the same politic views with them objectively." is in positive choices, lecturers should be told that they should evaluate the students who don't share the same politic views with them objectively.

As a result of the fact that attitude of $19 \%$ of the candidate teachers (24 candidate teachers) to the statement that "Educational administrators don't discriminate between the people who work at their service." is in positive choices, in order to learn that they shouldn't discriminate between the people who work at their service, an ambience in which administrators can take education should be created.

In view of the fact that attitude of $13 \%$ of the candidate teachers (17 candidate teachers) to the statement that "Educational administrators don't invest the people with whom they have same political view with certain positions" is in positive choices, educational administrators should be enlightened about the topic that they shouldn't appoint the people with whom they have same political view to certain authorities.

As a consequence of the fact that attitude of $15 \%$ of the candidate teachers (19 candidate teachers) to the statement that "Educational administrators don't favour the unqualified employees who have the same political view with them" is in positive choices, the idea that educational administrators shouldn't favour the unqualified employees who have the same political view with them should be given.

Bearing in mind that attitude of $14 \%$ of the candidate teachers (18 candidate teachers) to the statement that "Educational administrators don't prevent qualified employees who don't have the same political view from getting promotion" is in positive choices, administrators shouldn't prevent qualified employees who don't have the same political view from getting promotion.

As a consequence of the fact that attitude of $14 \%$ of the candidate teachers (18 candidate teachers) to the statement that "Educational administrators do everything in their power to make all the employees who have different political view unified." is in positive choices, administrators should have opportunities to do everything in their power to make all the employees who have different political view unified.

\section{REFERENCES}

[1] Adem, Mahmut. Educational Planning. Sevinç Press, Ankara, 1981.

[2] Başaran, İbrahim Ethem. Örgütlerde İşgören Hizmetlerinin Yönetimi. Ankara Üniversitesi Basımevi, Ankara, 1985.

[3] Bursalığlu, Ziya. The new structure and Behaviour at School Management. Ankara University The Faculty of Educational Sciences Press Number: 154, Extended 7th Press Ankara, 1987.

[4] Demirel, İhsan Nuri. Under 100 questions, The Planning of Education Management Inspection and Economy. 8th press, Ankara, 2017

[5] Field, A. Discovering statistics using IBM SPSS statistics. sage. 2013

[6] Kaya, Yahya Kemal. Eğitim Yönetimi, Bilim Yayınları, Geliştirilmiş Beşinci Baskı, Ankara, 1993. 
[7] Taymaz, Haydar. In Service Training. A.Ü. Education Faculty Press, Ankara, 1981.

[8] Mangin, M.M \& Stoelinga, S.R (2010). The Future of Instructional Teacher Leader Roles, The Educational Forum, Kappa Delta Pi, 74, 49-62.

[9] Hawley, W. D., and L. Valli. (1999). The Essentials of Effective Professional Development. In Teaching as the
Learning Profession: Handbook of Policy and Practice, ed. L. Darling Hammond and G. Sykes, 127-50. San Fran cisco: Jossey-Bass., II, 257-275.

[10] Garet, M. S., A. C. Porter, L. Desimone, B. F. Birman, and K. S. Yoon. (2001). What Makes Professional Development Effective? Results from a National Sample of Teachers. American Educational Research Journal, 38(4): 915-45. 